\title{
STUDY OF THE DAILY ENERGY REQUIREMENT OF THE CADETS FROM VASIL LEVSKI NATIONAL MILITARY UNIVERSITY
}

\author{
Pavlin Glushkov ${ }^{1}$, Simeon Simeonov ${ }^{2}$ \\ ${ }^{1}$ Ph.D., National Military University, Veliko Tarnovo, Bulgaria, pavlin_glushkov@mail.bg \\ ${ }^{2}$ Ph.D. Student, National Military University, Veliko Tarnovo, Bulgaria, sansiood@abv.bg
}

\begin{abstract}
The operative norms for nutrition of the military personnel are a result of the carried out in the 70-ies years of the past century research about the nutrition and the alimentary status of the servicemen and the achievements of the science of nutrition, the concepts for preparation and implementation of the Armies at that time. In this light the study of the actually consumed energy by the Cadets from Vasil Levski National Military University gives a suitable base for the elaboration of new rational norms of nutrition, which could correspond to the requirements for a healthy way of life.

Aim of the research is to determine the value of the daily energy requirement of the Cadets from Vasil Levski National Military University, which would serve as a starting point for elaboration of new standards of nutrition of the Cadets at Vasil Levski National Military University.

Object of research is the rational nutrition of the Cadets, as a component of the healthy way of life during the process of their education at Vasil Levski National Military University.

Subject of research is the actually consumed energy requirement of the Cadets during the process of their education at Vasil Levski National Military University.
\end{abstract}

Keywords: military personnel, norms, cadets, rational nutrition.

\section{INTRODUCTION}

At the beginning of the 21 st century the world community starts to realize and to redefine the crucial meaning of the problem of nutrition of the population. In world scale there exist Nutrition Institutes, where the problems of nutrition in the light of rational feeding of the population not only in the separate countries, but in the world overall, are being examined.

In the last years in the world can be observed a significant displacing of the sick rate of the population, including Bulgaria, which may is connected with the changes in nutrition and way of life. According to the specialists, such changes contribute to the epidemic of non-infectious diseases, such as: cardio-vascular diseases (coronary heart disease, hypertension and stroke), some cancer diseases, diabetes, obesity and others. According to the international ranking of the WHO, during the last decades in Bulgaria high mortality is maintained, linked with the diseases of the circulatory system and occupies one of the leading places in 
the world regarding mortality due to stroke.

The problematic, connected with the organization of feeding of the servicemen from the Ministry of Defense and from the Bulgarian Army is a process, which can't be isolated outside the scientific achievements and the tendencies in the sphere of protecting the health of the nation. Without any doubt, the Ministry of Defense is a part of the integrated effort for implementation of the National Action Plan "Foods and nutrition" - 2005-2010". The elaboration of this document is a result of the adopted by all countries-members of the WHP decisions for implementation of new policy in the sphere of nutrition, the aim of which is improvement of health. It's consistent with the contemporary requirements in the sphere of healthy nutrition and safety of foods, the European directives and recommendations and the gained long experience of Bulgarian scientists in this sphere.

It ought to be taken into account, that the operative norms for nutrition of the servicemen are a result of the carried out in the 70-ies years of the past century research about the nutrition and the alimentary status of the servicemen and the achievements of the science of nutrition, the concepts for preparation and implementation of the Armies at that time. In this light the study of the actually consumed energy by the servicemen and in particular by the Cadets from Vasil Levski National Military University during their process of their training gives a suitable base for the elaboration of new rational norms of consumption of various food products, consistent with the new economic conditions in the Republic of Bulgaria, which correspond to the requirements for a healthy way of life.

\section{STUDY OF THE DAILY ENERGY REQUIREMENT OF THE CADETS FROM VASIL LEVSKI NATIONAL MILITARY UNIVERSITY}

Basic stages of the examination ((Nichev, 2017a, pp. 399-404; Terziev, Nichev, 2017b, pp. 627-630; Terziev, Nichev, 2017c, pp. 846-850; Terziev, Nichev, 2017d, pp. 631-635; Terziev, Nichev, 2017e, pp. 667-671, Human energy requirements, 2001a; Westerterp, 2013a; Regulation, 2005a)

The basic stages of the used methodology for determination of the 24-hours energy requirement consist in:

Determination of the method for calculation of the daily energy requirement. Within the frames of this stage an examination of the methods for calculation of the daily energy requirement was carried out and as the most suitable was selected the method, offered by the United Nations Food and Agricultural Organization, WHO and the University of the UN, which was adapted to the specificity of the activity of the Military University.

Analysis of the methods of measuring the expenditures of time and selection of the most suitable method for the particular conditions. From the performed inspection of the methods of studying the time expenditures and the specificity of the educational process a conclusion is imposed, that the most suitable method to apply for the study of the 24-hours' time expenditure is the chronometry method.

Preliminary study of the main events, included in the distribution of time during the 24-hours period. Resulting from the analysis a chronogram of the organization and structure of the 24-hours period of the Cadets at "Vasil Levski" NMU, according to the time distribution, was prepared.

Analysis of the duration of the specific events from the time distribution during the 24-hours period. During the period 02.05.2017 - 12.05.2017 a group chronometry of the duration of the specific events, having the character of work activity, of the time distribution during the 24-hours period at Vasil Levski National Military University was carried out.

Determination of the norm of physical activity (NPA) for each sort of physical activity. Based on an analysis and recommendations of the United Nations Food and Agricultural Organization, a NPA for each single activity of the 24-hours period of the Cadets from Vasil Levski National Military University was determined.

Performing of an individual chronometry during the period 15.05.2017 - 19.05.2017.

Analysis of the obtained results.

\section{Analysis of the obtained results}

During the study of the daily energy requirement of the Cadets, the energy requirement of medical healthy, performing their usual tasks from the time distribution Cadets from Vasil Levski National Military University region Veliko Tarnovo, was evaluated. Totally 295 examinations of 59 Cadets had been carried out. All examined persons are at age within the limits 19-24 years and are students from first up to fifth course. The main characteristics of the examined group are listed in Table 1. 
Table 1. Characteristics of the examined group

\begin{tabular}{|c|c|c|c|c|}
\hline & & \multicolumn{3}{|c|}{ Cadets $(\mathrm{n}=295)$} \\
\hline Parameter & Unit & $\begin{array}{c}\text { Average } \\
\text { reading }\end{array}$ & $\begin{array}{c}\text { Standard } \\
\text { deviation }\end{array}$ & Range \\
\hline Age & Years & 21 & \pm 1 & $19-24$ \\
\hline Weight & $\mathrm{kg}$ & 72,1 & $\pm 13,6$ & $47,0-108,3$ \\
\hline Height & $\mathrm{cm}$ & 174,7 & $\pm 10,1$ & $150-196$ \\
\hline $\begin{array}{c}\text { Energy } \\
\text { requirement }\end{array}$ & $\begin{array}{c}\mathrm{kcal} / \\
\text { daily }\end{array}$ & 2673,6 & $\pm 518,3$ & $1651-4161$ \\
\hline $\begin{array}{c}\text { Level of } \\
\text { physical activity }\end{array}$ & & 1,56 & $\pm 0,13$ & $1,32-2,13$ \\
\hline
\end{tabular}

The age of the examined cadets is within the range $19-24$ years. $11.1 \%$ of the women and $14.1 \%$ of men are 19 years old. The histogram 1 illustrates the frequency of distribution of the whole examined group, while Figure 1 shows the percentage of age according to genders.

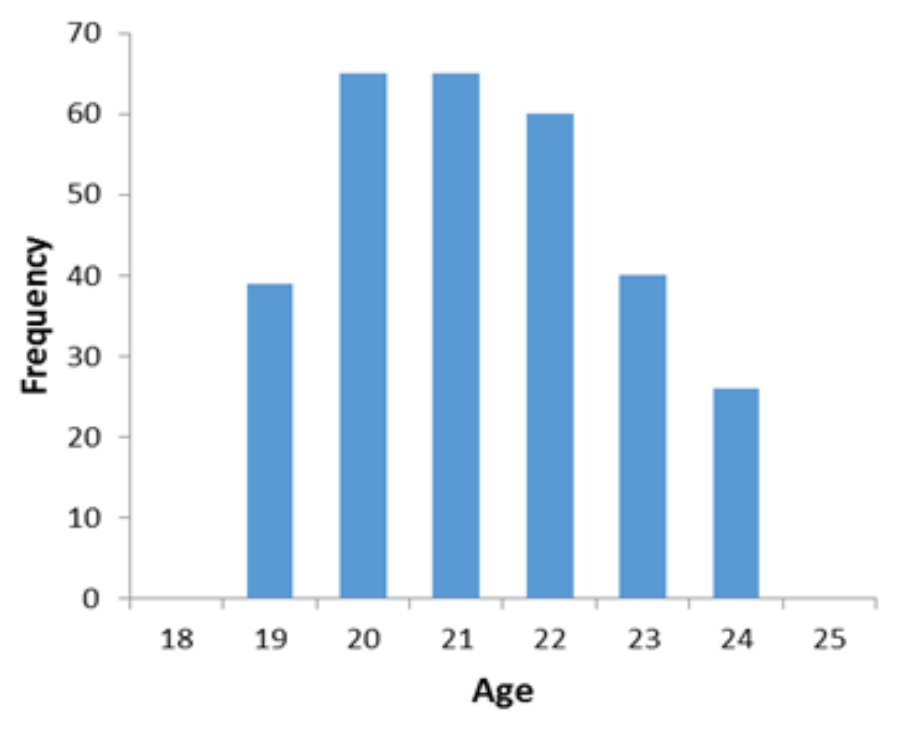

Histogram 1: Age distribution in years of the whole examined group.

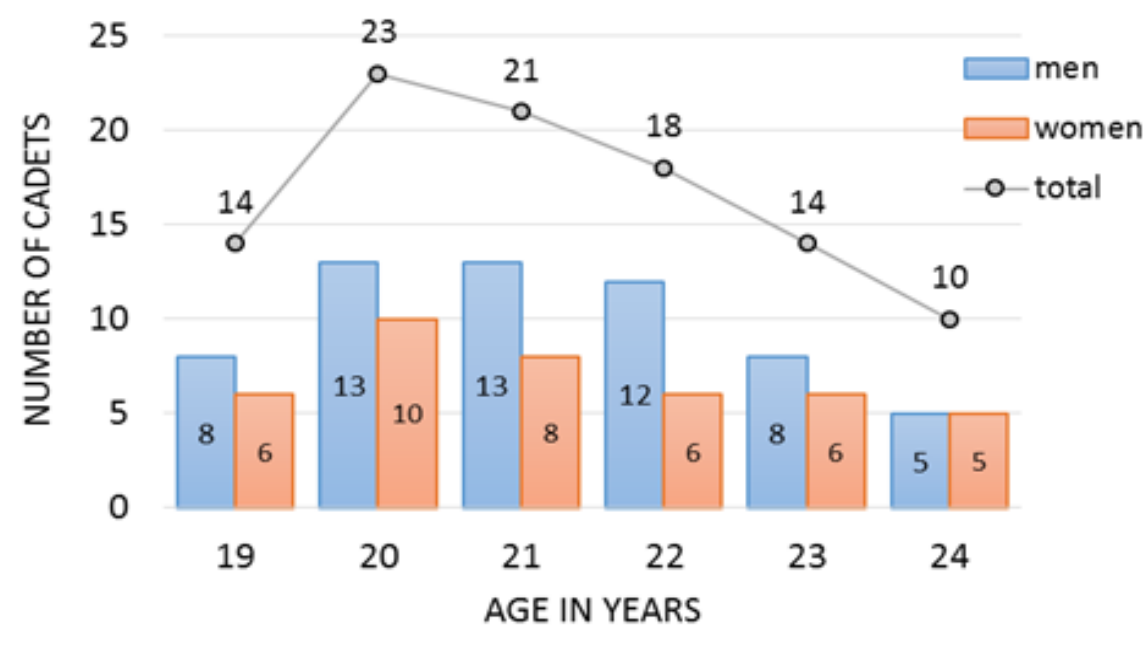

Fig. 1: Distribution of the examined persons according to age and gender.

\section{Levels of physical activity and time spent at different actions}

As Klaas Westerterp notes, the expenditures on energy effectiveness increase from $20 \%$ for the one year old children up to $35 \%$ for 18 -years old persons, where the teenagers spend averagely $9 \%$ of their active time on 
high intensity activities, while the corresponding share for adults is $4 \%$. On the contrary, children spend averagely $19 \%$ of their whole active time on high intensity activities. Because of the fact, that the daily energy requirement is directly dependent on the body weight, a far more suitable measuring factor is the level of physical activity. During the determination of the level limits of the physical activity, the data from the $\mathrm{WHO}$ have been used and the physiological norms of nutrition of the population in Bulgaria. The energy requirements are strongly dependent on the usual physical activity. For a deeper profundity of the analysis of the energy requirement of the Cadets from Vasil Levski NMU, the intensity of the usual physical activity of the students has been classified into four categories. For each category are determined the limits of the NPA values, not average values, same for women and men. It must be noted, that levels of physical activity, higher than 2.40, are difficult to be maintained during a long period of time.

At Table 2 are shown the levels of physical activity, connected by the everyday activities of the Cadets.

Table 2: Classification of the levels of physical activity

\begin{tabular}{|c|c|}
\hline Category & Level of physical activity \\
\hline Low & $1,40-1,69$ \\
\hline Moderate & $1,70-1,99$ \\
\hline High & $2,00-2,39$ \\
\hline Very high & Over 2,40 \\
\hline
\end{tabular}

At Figure 2 is illustrated the time duration, spent on different sorts of physical activity during the period 15.05.-21.05.2017. It's visible from the analysis of the performed by the Cadets activities, that the time spent on sleeping or educational activity form the major time volume of the low level of physical activity.

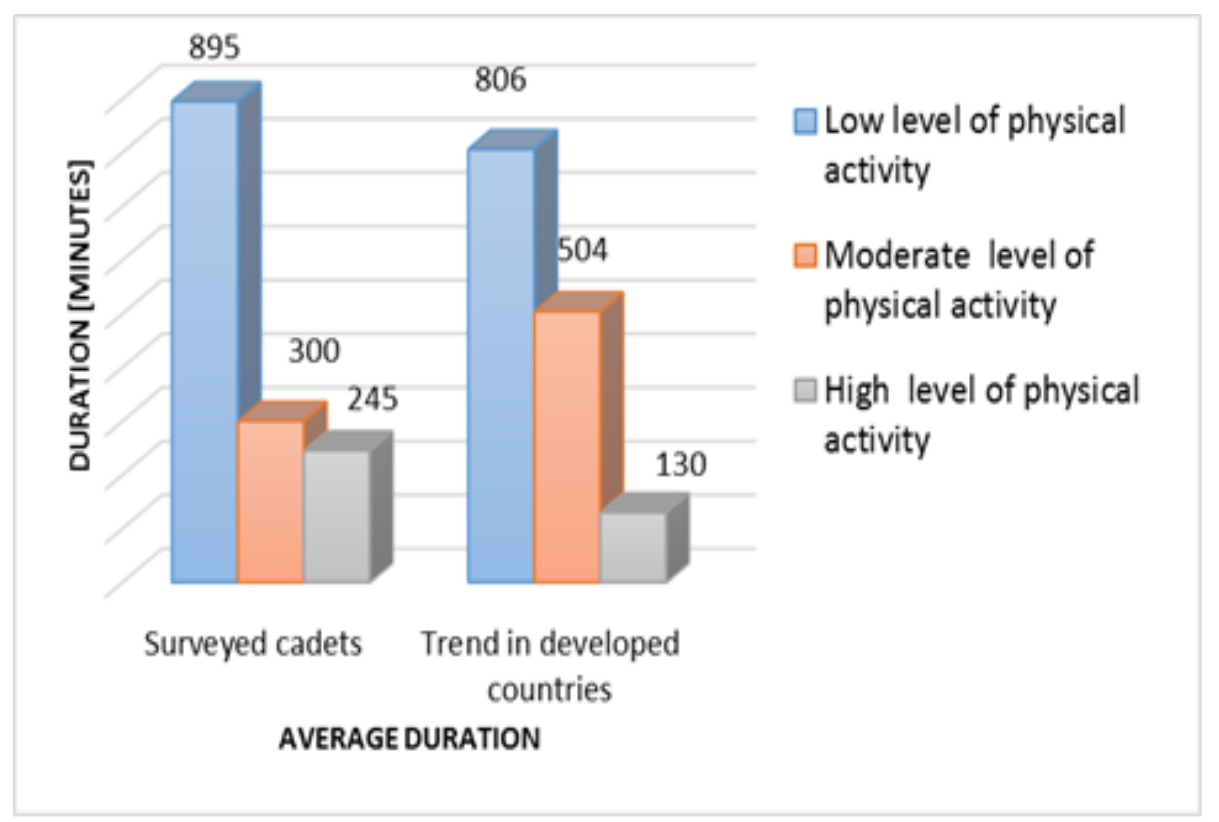

Fig. 2: Duration of the actions in the different sorts of physical activity.

On the days from Monday to Thursday at the low level of physical activity all activities, starting from rest (sleeping) and school hours are found, at the moderate level of physical activity prevails the official time, while the private time and a small part of the official time form the time, spent at the high level of physical activity. On Fridays, at the low level of physical activity, except the time spent on rest (sleeping) and the school hours also a big part of the official time $(37,3 \%)$ is included, while the bigger part of the private time $(80,6 \%)$ and a small part of the official activity $(10,2 \%)$ determine the moderate levels of physical activity, while the cleaning of the areas during the household half-day belong to the very high levels of physical activity (Table 3). 
IJASOS- International E-Journal of Advances in Social Sciences, Vol. IV, Issue 12, December 2018

Table 3: Time, spent at the different levels of physical activity

\begin{tabular}{|c|c|c|c|c|c|c|}
\hline \multirow{2}{*}{$\begin{array}{l}\text { Character of the } \\
\text { activity } \\
\begin{array}{c}\text { Day of the } \\
\text { week }\end{array}\end{array}$} & \multicolumn{2}{|c|}{ Cadets } & \multicolumn{4}{|c|}{ Time spent at the particular level of physical activity } \\
\hline & $\begin{array}{l}\text { Dura-tion } \\
\text { [min.] }\end{array}$ & $\begin{array}{c}\text { Average } \\
\text { NPA }\end{array}$ & Low & Mode-rate & High & $\begin{array}{l}\text { Very } \\
\text { high }\end{array}$ \\
\hline \multicolumn{7}{|c|}{ From Monday until Thursday } \\
\hline Rest (Sleep) & 480 & 1,00 & 480 & & & \\
\hline Official time & 140 & 1,70 & & 110 & 30 & \\
\hline School hours & 460 & 1,62 & 460 & & & \\
\hline Private time & 360 & 2,13 & & & 360 & \\
\hline Altogether & 1440 & & 940 & 110 & 390 & \\
\hline \multicolumn{7}{|l|}{ Friday } \\
\hline Rest (Sleep) & 480 & 1,00 & 480 & & & \\
\hline Official time & 295 & 1,89 & 110 & 30 & & 155 \\
\hline School hours & 305 & 1,34 & 305 & & & \\
\hline Private time & 360 & 2,06 & & 290 & 70 & \\
\hline Altogether & 1440 & & 895 & 320 & 70 & 155 \\
\hline
\end{tabular}

From the conducted research a conclusion is imposed, that the general energy requirement for female cadets is smaller than that of the male cadets. After giving an account of the body mass it becomes visible, that the female cadets consume almost the same quantity of energy, as the cadets-men. The small differences between the daily energy requirement for $1 \mathrm{~kg}$ of the body weight of the examined groups is owed to the fact, that the energy requirement of men on main metabolism is higher than that of women, because of the higher body mass, what leads to a higher general energy consumption, including the average daily energy requirement for $1 \mathrm{~kg}$ of the body mass. The general daily energy consumption and the daily energy requirement for $1 \mathrm{~kg}$ of the body mass for cadets-men and cadets-women are presented at Table 4 and Figures 3 and 4.

Table 4: Energy requirement of the examined Cadets

\begin{tabular}{|l|l|l|l|l|}
\hline $\begin{array}{l}\text { Examined } \\
\text { groups }\end{array}$ & $\begin{array}{l}\text { Number of } \\
\text { researches } \\
n\end{array}$ & $\begin{array}{l}\text { Average } \\
\text { reading } \\
\overline{\mathrm{x}}\end{array}$ & $\begin{array}{l}\text { Standards } \\
\text { deviation } \\
\sigma\end{array}$ & $\begin{array}{l}\text { Range } \\
\min -\max \end{array}$ \\
$\begin{array}{l}\text { Total daily energy requirement } \\
\text { [kcal/daily] }\end{array}$ & & & \\
\hline $\begin{array}{l}\text { Cadets } \\
\text { including }\end{array}$ & 295 & 2673,6 & $\pm 518,3$ & $1651-4161$ \\
\hline Men & 205 & 2941,5 & $\pm 358,0$ & $2346-4161$ \\
\hline Women & 90 & 2063,3 & \pm 227 & $1651-2729$ \\
\hline $\begin{array}{l}\text { Daily energy requirement on } 1 \mathrm{~kg} \text { of the body mass } \\
{[\mathrm{kcal} / \mathrm{kg}]}\end{array}$ & 295 & 37,2 & $\pm 3,7$ & $30,2-52,4$ \\
\hline $\begin{array}{l}\text { Cadets } \\
\text { including }\end{array}$ & 205 & 37,7 & $\pm 3,8$ & $30,4-52,4$ \\
\hline Men & 90 & 36,2 & $\pm 3,3$ & $30,2-50,5$ \\
\hline Women &
\end{tabular}




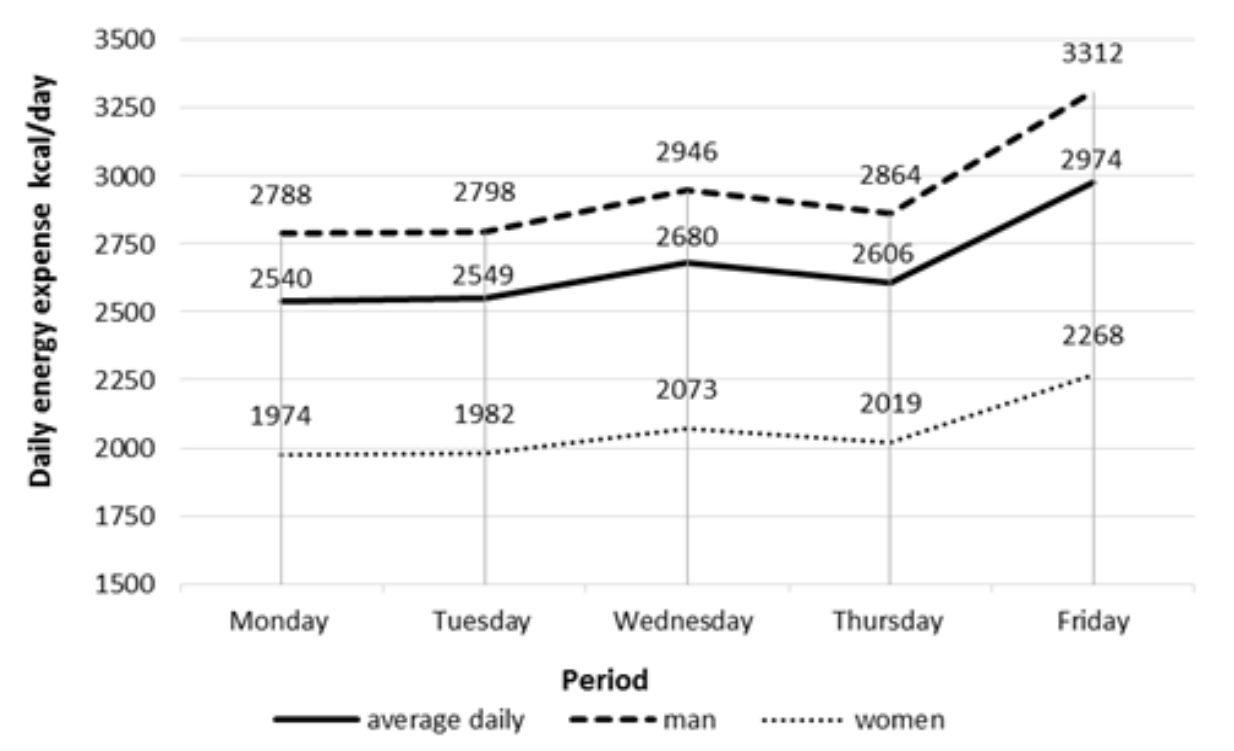

Fig. 3. Total daily energy requirement of the Cadets from Vasil Levski National Military University during the examined period.

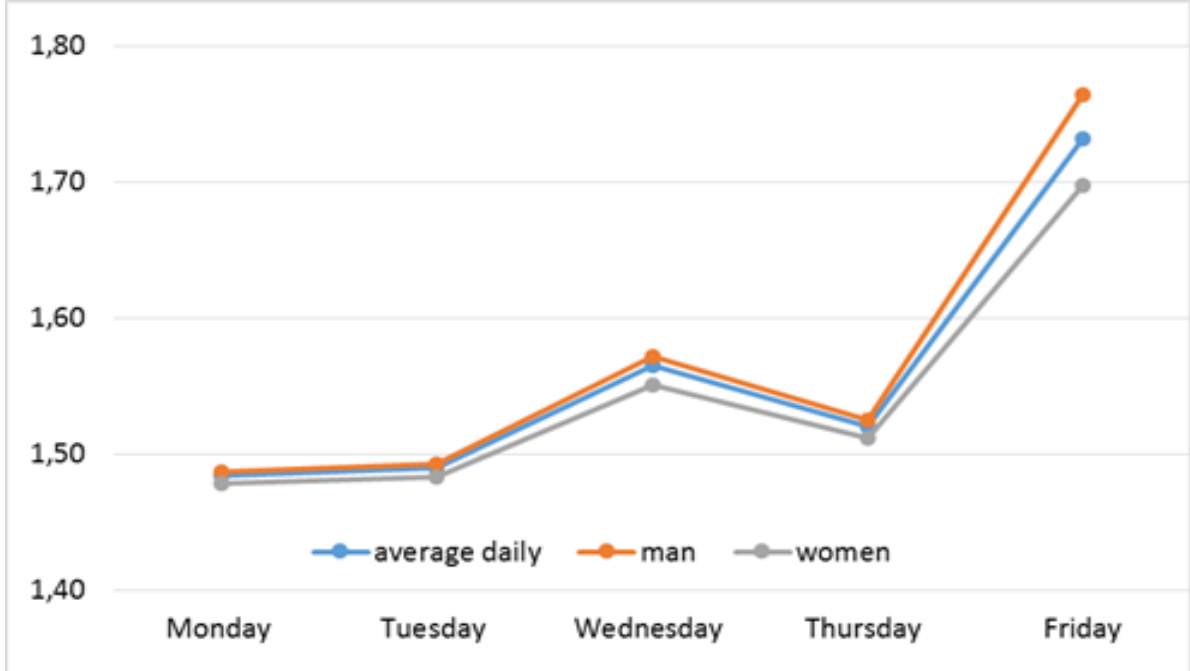

Fig.4. Daily energy requirement on $1 \mathrm{~kg}$ of the body mass of the Cadets from Vasil Levski NMU during the examined period.

The averagely weighed norm of physical activity for the performance of different sorts of muscle activity during the training of Officers of Tactical Management Level is equal to 1.52 and is placed in the middle of the range of values for the low level of physical activity. The average energy requirement for the performance of different sorts of physical activity amounts $37.3 \mathrm{kcal} / \mathrm{kg}$ of the body weight, where the corresponding values for the men are $37.7 \mathrm{kcal} / \mathrm{kg}$ and $36.2 \mathrm{kcal} / \mathrm{kg}$ for women.

During performance of field trainings and tactical day trainings, the daily energy requirements of the Cadets usually exceed $4200 \mathrm{kcal} /$ daily, and in days with a normal learning process the average daily energy is $2673,6 \mathrm{kcal} /$ daily. The cold environment and the high altitude create a tendency to increasing of the energy requirements, because the Cadets are normally wearing heavier clothing and equipment and are executing more intense activities in result of the reduced quantity of oxygen in the atmosphere air, the presence of a snow cover and the tough terrain. On the contrary, the hot environment doesn't increase or reduce the general energy requirements (Terziev, Nichev, 2017f, p.164; Terziev, Nichev, 2017g, pp.915-919; Terziev, Nichev, Bogdanov, 2017h, pp. 469-475; Terziev, Nichev, Bogdanov, 2017i, pp.671-677; Nichev, 2017j, str. 121-128; Nichev, 2017k, pp. 129-135; Kanev, Terziev, 2017l, pp.413-423; Kanev, Terziev. 2017m, pp. 595606; Sotirov, Terziev, 2015a, str. 197-207; Sotirov, Terziev, 2015b, p.25; Terziev, 2017n, pp. 893-908; Terziev, 2016a, s.84-90; Terziev. 2017o, p.252; Terziev, 2017p, pp.22-28; Terziev, Vezieva, Arabska, 2016b, str.106-121; Terziev, Manolov, 2016c, pp.15-20; Terziev, Minev, Sotirov, Ivanov, 2016d; Terziev. Kanev, 2017q, pp.733-742; Terziev, Madanski, 2017v, pp.917-937; Terziev, Madanski, 2017r, pp.28-36; 
Terziev, Madanski, 2017s, pp.610-625; Terziev, Madanski, Kanev, 2017t, pp.575-594; Terziev, Madanski, Kanev, 2017u, pp.396-415; Terziev, Madanski, Kanev, 2017v, pp.1331-1346; Terziev, Madanski, Kanev, 2017w, pp.1355-1372; Terziev, Madanski, Kanev, 2017x, pp.1380-1393; Terziev, Nichev, 2016e, pp.101106; Terziev, Nichev, 2017y, pp.661-666; Banabakova, Georgiev, 2018a, pp. 46-51; Banabakova, Georgiev, 2018b, pp. 462-467; Terziev, Manolov, 2016f, pp.307-318; Terziev, Manolov, 2016g, pp.15-29; Terziev, Manolov, 2016h, s.96-106; Terziev, Manolov, 2016i, pp.570-575; Terziev, Manolov, 2016j, pp.9-13).

\section{CONCLUSION}

The presented data illustrate the huge scope of the daily energy requirements of the Cadets from Vasil Levski National Military University. The energy requirements of the Cadets vary mainly depending on the quantity of physical activity, which is being accomplished. For the Cadets, studying in Vasil Levski NMU, the energy requirements for the securing of execution of different forms of mental and physical activities during the day, corresponds to a labor activity with a low intensity grade. Though, in the evaluation of this circumstance, it's necessary to take into account not only the scale of the energy requirements, but also the fact, that this kind of activity continues five years long at the Military University.

\section{REFERENCE LIST}

Nichev, N., (2017a). Research on the Preparation and Professional Realization of Newly Appointed Logistics Officers. // The 23rd International conference Knowledge-Based Organization, Volume XXIII No 2, Nicolae Balcescu Land Forces Academy, Sibiu, Romania, 2017, pp. 399-404.

Terziev, V., Nichev, N. (2017b). Analysis of the Environment for Military Educational System Functioning and Its Impact on the Preparation of Cadets for Military Professional Activities in the Republic of Bulgaria. // Proceedings of 4th International Conference on Education, Social Sciences and Humanities, 10-12 July 2017, OCERINT, Dubai, UAE, pp. 627-630, ISBN: 978-605-82433-1-6.

Terziev, V., Nichev, N. (2017c). Research on the Management Skills and Abilities Acquired in the Military Education System. // Central Bohemia University International Conference Proceedings 2017, Innovations in Science and Education, March 22-24, Published by Central Bohemia University, 2017, pp. 846-850, ISSN 1805-997X (Print), ISSN 1805-9961 (Online).

Terziev, V., Nichev, N. (2017d). Some Aspects on Forming Preparedness of Logistics Military Officers for Management Activities. // Proceedings of $4^{\text {th }}$ International Conference on Education, Social Sciences and Humanities, 10-12 July 2017, OCERINT, Dubai, UAE, pp. 631-635, ISBN: 978-605-82433-1-6.

Terziev, V., Nichev, N. (2017e). Streamlining Management Solutions for Economic, Effective and Efficient Spending of Resources for Security and Defense. Proceedings of $4^{\text {th }}$ International Conference on Education, Social Sciences and Humanities, 10-12 July 2017, OCERINT, Dubai, UAE, pp. 667-671, ISBN: 978-605-82433-1-6.

Human energy requirements. (2001a). Report of a Joint FAO/WHO/UNU Expert Consultation Rome, 17-24 October 2001.

Klaas R. Westerterp. (2013a). Physical activity and physical activity induced energy expenditure in humans: measurement, determinants, and effects. // Frontiers in Physiology, Volume 4, Article 90, 2013, www.frontiersin.org/articles/10.3389/fphys.2013.00090/full, on16.11.2017.

Regulation (2005a) Nr 23 from July, $19^{\text {th }} 2005$ of the Ministry of Healthcare of the Republic of Bulgaria about the physiological norms for nutrition of the population.

Terziev, V., Nichev, N. (2017f). Developing the readiness for the organizational activity of the cadets. // CBU International Conference Book of Abstracts, March 22-24, 2017, Prague, Czech Republic, Innovations in Science and Education, ISBN 978-80-88042-09-9, p.164.

Terziev, V., Nichev, N. (2017g)/ Developing the readiness for the organizational activity of the cadets. // CBU International Conference Proceedings 2017, March 22-24, Prague, Czech Republic, Innovations in Science and Education, 2017, SSN 1805-997X (Print), ISBN 978-80-88042-07-5 (Print edition), pp.915-919.

Terziev, V., Nichev, N., Bogdanov, P. (2017h). Comparative analysis of the formation of military professional 
skills in the cadets to be trained in logistics specializations. // IJAEDU- International E-Journal of Advances in Education, International Organization Center of Academic Research, www.ocerint.org, 3, 2017, N 9, pp. 469-475, (INT) e-ISSN: 2411-18.

Terziev, V., Nichev, N., Bogdanov, P. (2017i). Comparative analysis of the formation of military professional skills in the cadets to be trained in logistics specializations. // Proceedings of ADVED 2017- 3rd International Conference on Advances in Education and Social Sciences 9-11 October 2017- Istanbul, Turkey, 2017, ISBN: 978-605-82433-0-9, pp.671-677.

Nichev, N. (2017j). Ofsetna politika na stranite ot Evropeyskiya Sayuz. Spisanie za nauka „Novo znanie”, Akademichno izdatelstvo „Talant“, Visshe uchilishte po agrobiznes i razvitie na regionite, Plovdiv, Vol 6, No 1, 2017, str. 121-128, ISSN 2367-4598 (Online), ISSN 1314-5703 (Print) (Ничев, Н. Офрсетна политика на страните от Европейския Съюз. Списание за наука „Ново знание”, Академично издателство „Талант“, Висше училище по агробизнес и развитие на регионите, Пловдив, Vol 6 , No 1, 2017, стр. 121-128, (Online) ISSN 2367-4598, (Print) ISSN 1314-5703).

Nichev, N. (2017k). Perspektivi za izpolzvane na ofsetnite sdelki. Spisanie za nauka „Novo znanie”, Akademichno izdatelstvo "Talant“, Visshe uchilishte po agrobiznes i razvitie na regionite - Plovdiv, Vol 6, No 1, 2017, pp. 129-135, (Online) ISSN 2367-4598, (Print) ISSN 1314-5703 (Ничев, Н. Перспективи за използване на офсетните сделки. Списание за наука „Ново знание”, Академично издателство „Талант“, Висше училище по агробизнес и развитие на регионите Пловдив, Vol 6, No 1, 2017, pp. 129-135, (Online) ISSN 2367-4598, (Print) ISSN 1314-5703).

Kanev, D.,Terziev. V. (2017I). Behavioral economics: development, condition and perspectives. // IJASOSInternational E-Journal of Advances in Social Sciences, Vol. III, Issue 8, pp.413-423, e-ISSN: 2411$183 \mathrm{X}$.

Kanev, D.,Terziev. V. (2017m). Behavioral economics: development, condition and perspectives. // Proceedings of SOCIOINT 2017- 4th International Conference on Education, Social Sciences and Humanities 10-12 July 2017- Dubai, UAE, pp. 595-606, ISBN: 978-605-82433-1-6.

Sotirov, B., Terziev, V. (2015a). Predizvikatelstva i perspektivi pred obuchenieto po tehnologichni distsiplini. // Parva mezhdunarodna nauchna konferentsiya „Predizvikatelstva pred savremennite organizatsii, svarzani s postigane na ustoychivost - znanie i inovatsii v upravlenieto i funktsioniraneto",Plovdiv. ISBN 978-619-7246-04-9 (DVD), ISBN 978-619-7246-06-3 (e-book), str. 197-207, Сотиров, Б., Терзиев, В. Предизвикателства и перспективи пред обучението по технологични дисциплини. // Първа международна научна конференция „Предизвикателства пред съвременните организации, свързани с постигане на устойчивост - знание и иновации в управлението и функционирането“, 12 декември 2015 г., Пловдив, 2015, ISBN 978-619-7246-04-9 (DVD), ISBN 978-619-7246-06-3 (e-book), стр.197-207.

Sotirov, B., Terziev, V. (2015b). Challenges and perspectives to the training in technological subjects. // Book of Abstracts: First International Scientific Conference „Sustainability Challenges in Modern Organizations - Knowledge \& Innovation in Management \& Operation", p.25, ISBN 978-619-7246-03-2 (DVD), ISBN 978-619-7246-05-6 (e-book).

Terziev, Venelin. (2017n). National security of the republic of Bulgaria. // The Chinese Journal of International Politics, 10, 2017, N 4 (2), pp. 893-908, ISSN 1750-8916, Source Normalized Impact per Paper (SNIP): 1.901 SCImago Journal Rank (SJR): 1.238 Impact factor: 1.594 5-Yr impact factor: 1.747.

Terziev. V. (2016a). Human resource management systems in security and defense: social policies for social activities. // XXXII Mezhdunarodnaya nauchno-prakticheskaya konferentsiya, Evraziyskiy soyuz uchenayh (ESU), Ezhemesyachnayy nauchnayy zhurnal №12 (33)/ 2016 Chasty 1, Moskva 30.12.2016g., s.84-90, ISSN 2411-6467 (Terziev, Venelin. Human resource management systems in security and defense: social policies for social activities. // XXXII Международная научнопрактическая конференция, Евразийский союз ученых (ЕСУ), Ежемесячный научный журнал № 12 (33)/ 2016 Часть 1, Москва 30.12.2016г., 2016, с.84-90, ISSN 2411-6467).

Terziev. V. (2017o). Entry Opportunities in the Bulgarian Military - Educational System and Ensuring of Civil Rights. $/ / 3^{\text {rd }}$ Central and Eastern European LUMEN International Scientific Conference New Approaches in Social and Humanistic Sciences 8-10 June 2017, Chisinau, Republic of Moldova, 2017, ISBN: 978-973-166-461-3, p.252.

Terziev. Venelin. (2017p). National security of the republic of Bulgaria. // International Journal of 
IJASOS- International E-Journal of Advances in Social Sciences, Vol. IV, Issue 12, December 2018

Management and Applied Science, 3, 2017, N 4, ISSN: 2394-7926, pp.22-28.

Terziev, V., Vezieva, D., Arabska, E. (2016b). Balgarskite universiteti i vazmozhnostite na Operativna programa „Nauka i obrazovanie za inteligenten rastezh". // Mezhdunarodna nauchna konferentsiya „Obrazovanie, nauka, ikonomika i tehnologii“ 23-24 yuni $2016 \mathrm{~g}$. Akademichno spisanie „Upravlenie i obrazovanie“", 12, 2016, N 1, ISSN 1312-6121, str.106-121 (Терзиев, В., Везиева, Д., Арабска, Е. Българските университети и възможностите на Оперативна програма „Наука и образование за интелигентен растеж". // Международна научна конференция „Образование, наука, икономика и технологии“ 23-24 юни 2016 г. Академично списание „Управление и образование“, 12, 2016, N 1 , ISSN 1312-6121, стр.106-121).

Terziev, V., Manolov, D. (2016c). Creation of good organizational environment for scientific research activity (Създаване на добра организационна среда за научноизследователска дейност) // Актуальные проблемы глобализации, Салоники, Греция (Actual problems of globalization, August 29, 2016, Thessaloniki, Greece), Scientific journal «Economics and Finance», Actual problems of globalization Collection of scientific articles, 2016, ISBN 978-617-7214-34-1, pp.15-20.

Terziev, V., Minev, R., Sotirov, B., Ivanov, K. (2016d). Vazmozhnosti za izgrazhdane na tsentar za kompetentnost $v$ Severen tsentralen rayon na Republika Balgariya. // Godishna universitetska nauchna konferentsiya, 20-21 oktomvri 2016 g. NVU „Vasil Levski“- Veliko Tarnovo. Sbornik dokladi tom 2, Nauchni napravleniya „Prirodomatematicheski nauki” i „Tehnicheski nauki”, ISSN 1314-1937.

Terziev. V., Kanev, D. (2017q). Education and Behavioural Failures. // Proceedings of ADVED 2017- 3rd International Conference on Advances in Education and Social Sciences 9-11 October 2017- Istanbul, Turkey, pp.733-742, ISBN: 978-605-82433-0-9.

Terziev, V, Madanski, V. (2017v). Development of military education system in Bulgaria. // American Journal of Education, The University of Chicago Press, 2017, 123, 2017, N 4 (2), ISSN: 0195-6744, pp.917937.

Terziev, V, Madanski, V. (2017r). Guidelines for development of military education system in Bulgaria (Nasoki za razvitie na voennoobrazovatelnata sistema na Balgariya). // Topical questions of contemporary science, United States of America 2017, ISBN 978-0-9988732-1-3, pp.28-36.

Terziev, V, Madanski, V. (2017s). Guidelines for development of military education system in Bulgaria. // Proceedings of the VII International Academic Congress "Fundamental and Applied Studies in EU and CIS Countries" (United Kingdom, Cambridge, England, 26-28 February 2017), Cambridge University Press, ISBN: 978-0-875-83597-4, 7, 2017, pp.610-625.

Terziev, V, Madanski, V., Kanev, D. (2017t). Entry opportunities in the bulgarian military-educational system and ensuring of civil rights. // Proceedings of SOCIOINT 2017- 4th International Conference on Education, Social Sciences and Humanities 10-12 July 2017- Dubai, UAE, 2017, ISBN: 978-60582433-1-6, pp.575-594.

Terziev, V, Madanski, V., Kanev, D. (2017u). Entry opportunities in the bulgarian military-educational system and ensuring of civil rights. // IJAEDU- International E-Journal of Advances in Education, 3, 2017, N 8 , e-ISSN:2411-1821, pp.396-415.

Terziev, V, Madanski, V., Kanev, D. (2017v). Entry opportunities in the Bulgarian military-educational system. // Sport, Education and Society, Taylor \& Francis, 22, 2017, N 8(2), Source Normalized Impact per Paper (SNIP): 1.459 SCImago Journal Rank (SJR): 1.005 Impact factor: 1.269 Ranking: 60/230 (Education \& Educational Research), 20/44 (Hospitality, Leisure, Sport and Tourism), $51 / 82$ (Sport Sciences), Print ISSN: 1357-3322, Online ISSN: 1470-1243, pp.1331-1346.

Terziev, V, Madanski, V., Kanev, D. (2017w). Condition and capabilities of the military-educational system of the Republic of Bulgaria. // Sport, Education and Society, Taylor \& Francis, 22, 2017, N 8(2), Source Normalized Impact per Paper (SNIP): 1.459 SCImago Journal Rank (SJR): 1.005 Impact factor: 1.269 Ranking: 60/230 (Education \& Educational Research), 20/44 (Hospitality, Leisure, Sport and Tourism), 51/82 (Sport Sciences), Print ISSN: 1357-3322 Online ISSN: 1470-1243, pp.1355-1372.

Terziev, V, Madanski, V., Kanev, D. (2017x). Directions for improvement of the military-educational system and its contribution for strengthening national security and the defence of the country. // Sport, Education and Society, Taylor \& Francis, 22, 2017, N 8(2), Source Normalized Impact per Paper (SNIP): 1.459 SCImago Journal Rank (SJR): 1.005 Impact factor: 1.269 Ranking: 60/230 (Education \& Educational Research), 20/44 (Hospitality, Leisure, Sport and Tourism), 51/82 (Sport Sciences), Print ISSN: 1357-3322 Online ISSN: 1470-1243, pp.1380-1393. 
IJASOS- International E-Journal of Advances in Social Sciences, Vol. IV, Issue 12, December 2018

Terziev, V., N.Nichev. (2016е). Икономически характеристики на офсетните сделки с отбранителни продукти (Economic characteristics of offset transactions with defense products). // Scientific journal „Economics and Finance“, Problems of development modern science: Theory and practice Collection of scienfic articles, 2016, ISBN 978-617-7214-33-4, pp.101-106.

Terziev. V., N.Nichev. (2017y). Main features of the offsets in defense trade. Proceedings of SOCIOINT 2017- 4th International Conference on Education, Social Sciences and Humanities 10-12 July 2017Dubai, UAE, 2017, ISBN: 978-605-82433-1-6, pp.661-666.

Banabakova, V., Georgiev, M. (2018a). Military professional forming of the cadets at Vasil Levski National Military University. // IJAEDU- International E-Journal of Advances in Education, April 2018, Turkey, International Organization Center of Academic Research, www.ocerints.org, Istanbul, Turkey, 2018, pp. 46-51, 4, 2018, N 10, e-ISSN: 2411-1821.

Banabakova, V., Georgiev, M. (2018b). Military professional forming of the cadets at Vasil Levski National Military University. // Proceedings of INTCESS2018- 5th International Conference on Education and Social Sciences 5-7 February 2018- Istanbul, Turkey, International Organization Center of Academic Research, www.ocerints.org, Istanbul, Turkey, 2018, pp. 462-467, ISBN 978-605-82433-2-3.

Terziev, V., Manolov, D. (2016f). Методика за планиране на снабдяването с вещево имущество в ресурсно ограничена среда (Methodology for planning of supply with clothes, shoes and equipment in Bulgarian armed forces). // Tenth International Scientific Conference The power of knowledge, 7-9 October 2016, Agia Triada, Republic of Greece, Knowledge International Journal Scientific papers, Institute of Knowledge Management, Skopje, 14, 2016, N 1, ISSN 1857-92, pp.307-318.

Terziev, V., Manolov, D. (2016g). Изграждане на капацитет в публичните служби за заетост (Capacity building in public employment services). // Scientific journal „Economics and Finance“, Problems of development modern science: Theory and practice - Collection of scienfic articles, 2016, ISBN 978617-7214-33-4, pp.15-29.

Terziev, V., Manolov, D. (2016h). Particular features of carrying out a procurement procedure at the Ministry of Defense. // XIII Mezhdunarodnaya nauchno-prakticheskaya konferentsiya „Sotsialynoekonomicheskie nauki i gumanitarnaye issledovaniya”, g. Novosibirsk, 28 lyunya, 25 lyulya 2016 g., ISBN 978-5-00068-616-4, s.96-106, Terziev, V., Manolov, D. Particular features of carrying out a procurement procedure at the Ministry of Defense. // XIII Международная научно-практическая конференция „Социально-экономические науки и гуманитарные исследования”, г. Новосибирск, 28 Июня, 25 Июля 2016 г., ISBN 978-5-00068-616-4, с.96-106.

Terziev, V., Manolov, D. (2016i). Систематизация на първична информация в статистически редове в планирането на снабдяването с вещево имущество в Българската армия (Systematization of original information in statistical rows in the planning of supply with clothes and equipment in Bulgarian armed forces). // Tenth International Scientific Conference The power of knowledge , 7-9 October 2016, Agia Triada, Republic of Greece, Knowledge International Journal Scientific papers, Institute of Knowledge Management, Skopje, 14, 2016, N 2, ISSN 1857-92, pp.570-575.

Terziev, V., Manolov. D. (2016j). Analysis of NATO logistics handbook. // Scientific journal „Economics and finance“, Verlag SWG imex GmbH, Nurnberg, Deutshland, Trends in der Entwicklung der nationalen und internationalen Wissenschaft, 2016, ISBN 978-617-7214-44-0, pp.9-13. 